\title{
Comparison of different procedures to map reference evapotranspiration using geographical information systems and regression-based techniques
}

\author{
S. M. Vicente-Serrano, ${ }^{\mathrm{a}} *$ S. Lanjeri ${ }^{\mathrm{b}}$ and J. I. López-Moreno ${ }^{\mathrm{c}}$ \\ a Instituto Pirenaico de Ecología, CSIC (Spanish Research Council), Campus de Aula Dei, Zaragoza 50080, Spain

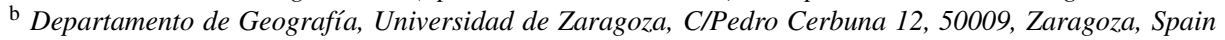 \\ ${ }^{\mathrm{c}}$ Department of Geosciences, University of Fribourg, Perolles, $\mathrm{CH}-1700$, Switzerland
}

\begin{abstract}
:
This paper compares different procedures for mapping reference evapotranspiration $\left(\mathrm{ET}_{\mathrm{o}}\right)$ by means of regression-based techniques and geographical information systems (GIS). ET $_{\mathrm{o}}$ is calculated following the method of Hargreaves (HG) from a dense database of meteorological stations in the northernmost semi-arid region of Europe, the Ebro valley. The HG method requires the calculation of estimates of extraterrestrial radiation $\left(R_{\mathrm{a}}\right)$. We calculated this parameter using two approaches: (1) the common approach that assumes a planar surface and determines the parameter as a function of latitude and (2) using a digital terrain model (DTM) and GIS modelling. The maps were made on a monthly basis using both approaches. We also compared possible propagations of errors in the map calculations for maps derived from modelled layers of maximum and minimum temperatures with those modelled using previously determined local $\mathrm{ET}_{\mathrm{o}}$ calculations. We demonstrate that calculations of $R_{\mathrm{a}}$ from a DTM and GIS modelling provide a more realistic spatial distribution of $\mathrm{ET}_{\mathrm{o}}$ than those derived by only considering latitude. It is also preferable to model in advance the variables involved in the calculation of $\mathrm{ET}_{\mathrm{o}}$ (temperature and $R_{\mathrm{a}}$ ) and to subsequently calculate $\mathrm{ET}_{\mathrm{o}}$ by means of layer algebra in the GIS rather than directly model the local $\mathrm{ET}_{\mathrm{o}}$ calculations. The obtained maps are useful for the purposes of agriculture and ecological and water resources management in the study area. Copyright (C) 2007 Royal Meteorological Society
\end{abstract}

KEY WORDS reference evapotranspiration; geographical information systems; regression-based interpolation; digital terrain models; Hargreaves method; Ebro valley; Spain

\section{INTRODUCTION}

Evapotranspiration represents the sum of the volume of water used by vegetation (transpiration), evaporated from the soil, and intercepted as precipitation. Water entering the evaporation phase of the hydrological cycle becomes unavailable for the generation of runoff or replenishment of groundwater (Doorenbos and Pruitt, 1977; Sharma, 1985; Jensen et al., 1990; Tsanis and Naoum, 2003; Pereira et al., 1999). Globally, an average of $57 \%$ of the annual precipitation returns to the atmosphere via evapotranspiration, and this value may reach $90-100 \%$ in arid or desert areas (Sanchez-Toribio, 1992). Seasonal evapotranspiration mainly depends on the characteristics of the weather and plant cover (structure, density, vegetative cycle). The concept of a reference evapotranspiration $\left(\mathrm{ET}_{\mathrm{o}}\right)$ can be used to estimate the effect of climate on evapotranspiration, and represents the evapotranspiration from a hypothetical reference surface (Allen et al., 1994).

\footnotetext{
* Correspondence to: S. M. Vicente-Serrano, Instituto Pirenaico de Ecología, CSIC (Spanish Research Council), Campus de Aula Dei, Zaragoza 50080, Spain. E-mail: svicen@ipe.csic.es
}

The quantification of $\mathrm{ET}_{\mathrm{o}}$ is a difficult task because of the numerous parameters involved in this process, e.g. surface temperature, air humidity, soil incoming radiation, water vapour pressure, and ground-atmosphere latent and sensible heat fluxes (Allen et al., 1998). Different methods have been developed to indirectly estimate $\mathrm{ET}_{\mathrm{o}}$ from various meteorological parameters measured at weather stations. According to data availability, such methods include physically based methods (i.e. the Penman-Monteith [PM] method) and models based on empirical relationships where $\mathrm{ET}_{\mathrm{o}}$ is calculated with fewer data requirements (e.g. the Hargreaves [HG] equation) (Sánchez-Toribio, 1992; Allen et al., 1998; Xu and Singh, 2001). In any case, $\mathrm{ET}_{\mathrm{o}}$ calculations based on meteorological data are punctual in space. Although these estimates may be useful for the management of agriculture, ecology, and water resources in homogeneous areas, in regions with complex climatology and topography, local estimates may not be representative of $\mathrm{ET}_{\mathrm{o}}$ over large areas (Blackie and Simpson, 1993). For this reason, inhomogeneous regions require the compilation of detailed maps to accurately describe spatial variations in $\mathrm{ET}_{0}$. 
A number of studies have demonstrated the reliability of statistical techniques in mapping climatic variables such as precipitation, temperature, and solar radiation; however, few studies have addressed the task of mapping ET $_{\text {o }}$ (e.g. Martínez-Cob, 1996; Antonic et al., 2001; Ray and Dadhwal, 2001; Dalezios et al., 2002; Häntzschel et al., 2005; Mardikis et al., 2005). Most of the procedures are based on local estimates of $\mathrm{ET}_{\mathrm{o}}$ from meteorological data collected at available weather stations. The calculated values are then interpolated using local or geostatistical methods.

Most of these interpolation techniques do not take into account the effect of relief and other geographic variables on spatial variations in $\mathrm{ET}_{\mathrm{o}}$. Mardikis et al. (2005) showed in a study in Greece that the inclusion of elevation data significantly improves the performance of interpolation methods used to map $\mathrm{ET}_{\mathrm{o}}$. The same result was observed in Oregon (USA) by MartínezCob and Cuenca (1992). Topography also affects the spatial variation in $\mathrm{ET}_{\mathrm{o}}$ because it noticeably affects the total solar radiation received by a surface. Therefore, Häntzschel et al. (2005) showed for a small region of South Germany that the daily sum of $\mathrm{ET}_{\mathrm{o}}$ on a steep south-facing spruce-covered surface is two times higher than the value of $\mathrm{ET}_{\mathrm{o}}$ on a north-facing grassy surface.

For these reasons, it seems sensible that the use of interpolation techniques should take into account the possible effect of geographical and topographical variables on spatial variations in $\mathrm{ET}_{\mathrm{O}}$. Such techniques are known as global techniques, and are based on deterministic models and the use of a digital terrain model (DTM) and geographic information systems (GIS) (Burrough and McDonnell, 1998; Dyras et al., 2005). A number of studies have demonstrated the vast potential of these techniques in mapping different climate variables, as the method provides significant improvements over results from local and geostatistical methods (e.g. Agnew and Palutikof, 2000; Ninyerola et al., 2000, 2006; Daly et al., 2002, 2003; Brown and Comrie, 2002; Vicente-Serrano et al., 2003; Hong et al., 2005; Ustrnul and Czekierda, 2005; Perry and Hollis, 2005; Beguería and VicenteSerrano, 2006; López-Moreno and Nogués-Bravo, 2005). However, no attempt has been made to map $\mathrm{ET}_{\mathrm{o}}$ using these techniques. To address this anomaly, in the present paper we analyse the usefulness of global interpolation methods and GIS technologies in mapping $\mathrm{ET}_{\mathrm{o}}$. The study was repeated at monthly intervals to test for seasonal differences in mapping performance.

The study area is the Ebro valley, the northernmost semi-arid region of Europe, in which water availability is low and the management of water resources is a priority task. The maps obtained in this research might be very useful for the management of agriculture, ecology, and water resources in this region. As the Ebro valley is usually isolated from humid air masses by mountains to the north and south, variability in precipitation is very important for this area (Vicente-Serrano and LópezMoreno, 2006b), as it affects reservoir storage levels
(López-Moreno et al., 2002, 2005), river flow (LópezMoreno and García-Ruiz, 2004), crop production (Austin et al., 1998), and vegetation growth (Vicente-Serrano, 2006). In addition, aridity is high in this area and extreme droughts are relatively common (Vicente-Serrano and Beguería-Portugués, 2003). The area has recorded a general increase in the severity and temporal variability of droughts (Vicente-Serrano and Cuadrat, 2006a), and this leads to greater uncertainty concerning future water availability and possible negative consequences in terms of the local ecology, social well-being, and economy (Herrero and Aragüés, 1988; Lasanta et al., 2001; Embid, 2003; Vicente-Serrano et al., 2006). For these reasons, it is necessary to obtain good spatial knowledge of the different processes that influence the availability of water resources. In this regard, $\mathrm{ET}_{\mathrm{o}}$ is one of the most important factors to consider.

At present, one of the most important research tasks in geographical information science is determining the quality of the layers (digital maps) used for environmental studies and management purposes. A related problem is the potential propagation of errors that occurs when GIS layers are overlapped and used for layer algebra (Lantner and Veregin, 1992; Haining and Arbia, 1993; Heuvelink and Burrough, 2002).

In the present study, we test different procedures used to calculate $\mathrm{ET}_{\mathrm{o}}$ to determine if error propagation significantly affects the reliability of the predictions. In other words, we seek to determine if it is preferable to model in advance the different variables involved in the calculation of $\mathrm{ET}_{\mathrm{o}}$ and obtain $\mathrm{ET}_{\mathrm{o}}$ by means of layer algebra within the GIS environment, or whether it is better to calculate $\mathrm{ET}_{\mathrm{o}}$ locally (at the location of the weather station) and then to later model the calculated $\mathrm{ET}_{\mathrm{o}}$ to avoid error propagation. We also discuss the role of estimating potential incoming solar radiation from a digital elevation model (DEM) that considers topographical complexity, given that most estimates are currently based on a planar surface and are calculated solely as a function of latitude (Allen et al., 1998).

\section{METHODOLOGY}

\section{Calculation of reference evapotranspiration}

A number of different methods are used to calculate $\mathrm{ET}_{\mathrm{o}}$ (Allen et al., 1998). In recent decades, the International Commission for Irrigation (ICID), the Food and Agriculture Organization of the United Nations (FAO), and the American Society of Civil Engineers (ASCE) have adopted the PM method (Allen et al., 1998; Walter et al., 2000) as the standard for computing $\mathrm{ET}_{\mathrm{o}}$ from climate data. The PM method is widely used because

(1) it is predominantly a physically based approach and as such it can be used globally;

(2) it has been widely tested using lysimeter data from a wide range of climate conditions (Allen et al., 1994; Itenfisu et al., 2000) 
The main drawback of the PM method is the relatively large amount of data involved, as it requires values for solar radiation, temperature, wind speed, and relative humidity. In the Ebro valley, Spain, as in numerous other regions, a scarcity of meteorological data is a frequent problem. As a result, there are very few sites within the valley for which all the parameters required for the PM method are recorded. Accordingly, it is not feasible to use the PM method to compile detailed $\mathrm{ET}_{\mathrm{o}}$ maps at a regional scale.

Several authors have proposed the empirical HG equation (Hargreaves and Samani, 1985) as the best alternative where data are scarce (e.g. Xu and Singh, 2001; Droogers and Allen, 2002; Martinez-Cob, 2002). This method only requires information on maximum and minimum temperature and extraterrestrial radiation $R_{\mathrm{a}}$. Because $R_{\mathrm{a}}$ can be calculated theoretically (Droogers and Allen, 2002), the only parameters required in this method are observed maximum and minimum temperatures. The HG method can be calculated daily, although better results are obtained for weekly to monthly timescales (Jensen et al., 1990; Choisnel et al., 1992; Droogers and Allen, 2002; Hargreaves and Allen, 2003). There have been attempts to locally calibrate the $\mathrm{HG}$ method to the PM method via empirical equations (Amatya et al., 1995; Droogers and Allen, 2002; Hargreaves and Allen, 2003; Martínez-Cob and Tejero-Yuste, 2004; Gavilán et al., 2006). This has mainly been attempted for daily time intervals because the HG method generally fails to accurately estimate $\mathrm{ET}_{\mathrm{o}}$ at this interval (Berengena and Gavilán, 2005; Temesgen et al., 2005).

At monthly and annual timescales, $\mathrm{ET}_{\mathrm{o}}$ estimates derived from the $\mathrm{HG}$ and PM methods are very similar (differences less than $\pm 2 \mathrm{~mm} \mathrm{day}^{-1}$ ) (Droogers and Allen, 2002). In fact, for the entire area of Eurasia, the difference between the annual average values of $\mathrm{ET}_{\mathrm{o}}$ derived from the $\mathrm{HG}$ and PM methods is close to zero (Droogers and Allen, 2002). Hargreaves and Allen (2003) showed that the relationship between monthly $\mathrm{ET}_{\mathrm{o}}$ calculated via the $\mathrm{HG}$ method and that measured by lysimeter varies between 0.97 and 1.01 for different semi-arid and sub-humid regions of the United States. In the Ebro valley, Martínez-Cob (2002) and MartínezCob and Tejero-Yuste (2004) showed that the HG method provides very similar results to those obtained from the PM equation (5-10\% difference). For a mountainous area north of the Ebro valley, López-Moreno et al. (2003) showed that $\mathrm{ET}_{\mathrm{o}}$ values estimated under humid conditions using the $\mathrm{HG}$ method are very similar to estimates obtained from the PM method.

The HG method is defined by the following equation (Hargreaves, 1985):

$$
\mathrm{ET}_{\mathrm{o}}=0.0023 \cdot R_{a} \cdot T D^{0.5}(T m+17.8)
$$

where $\mathrm{ET}_{\mathrm{o}}$ is the daily reference evapotranspiration (monthly average). To obtain the total monthly evapotranspiration, the result must be multiplied by the number of days in the month.
$T D$ is the difference between the maximum and minimum temperatures in ${ }^{\circ} \mathrm{C}$ (monthly averages).

$T_{\mathrm{m}}$ is the average monthly temperature.

$R_{\mathrm{a}}$ is extraterrestrial radiation in $\mathrm{mm} \mathrm{day}^{-1}$.

$R_{\mathrm{a}}$ is usually calculated theoretically as a function of latitude and the month of the year (Allen et al., 1998). This procedure assumes a planar surface that receives equal solar radiation at every site on the plane. At very detailed spatial resolutions and in areas with complex relief, this assumption may result in errors in $\mathrm{ET}_{\mathrm{o}}$ estimates because the terrain geometry and slope angle affect illumination and the total radiation received at the surface, which in turn affects $\mathrm{ET}_{\mathrm{o}}$ values (Häntzschel et al., 2005).

At present, the use of GIS and DEMs enables the calculation of $R_{\mathrm{a}}$ while taking into account characteristics of the terrain (e.g. Dubayah and Rich, 1995; Kumar et al., 1997; McKenney et al., 1999). Such calculations would provide more realistic values to use in $\mathrm{ET}_{\mathrm{o}}$ calculations.

In the present study, we calculated monthly $\mathrm{ET}_{\mathrm{o}}$ using two variations to the HG method:

(1) $R_{\mathrm{a}}$ is calculated theoretically as a function of latitude and the month of the year and (2) $R_{\mathrm{a}}$ values are modelled from a DEM with a cell size of $100 \mathrm{~m}$. For this purpose, we used an algorithm that considers the effects of terrain complexity (shadowing and reflection) and the daily solar position (Pons, 1996) that is implemented in the MiraMon GIS software (Pons, 2006). $R_{\mathrm{a}}$ is provided in $\mathrm{MJ} \mathrm{m}^{-2} \mathrm{day}^{-1}$, which is transformed to $\mathrm{mm} \mathrm{day}^{-1}$ according to the method of Allen et al. (1998): $1 \mathrm{MJ} \mathrm{m}^{-2}$ day $^{-1}=$ $0.408 \mathrm{~mm} \mathrm{day}^{-1}$. The purpose of using these two approaches is to assess the influence of topographic complexity on calculations of $\mathrm{ET}_{\mathrm{o}}$.

Figure 1 shows a DEM of part of the Ebro valley. The modelled daily average $R_{\mathrm{a}}$ for January is shown in the lower part of the figure. This map enables us to consider the important differences in $R_{\mathrm{a}}$ values between northfacing (low $R_{\mathrm{a}}$ ) and south-facing slopes (high $R_{\mathrm{a}}$ ). In the Ebro valley, annual $R_{\mathrm{a}}$ values vary between 75.3 and $164.1 \mathrm{~mm} \mathrm{day}^{-1}$. In contrast, when latitude is the only variable used to estimate $R_{\mathrm{a}}$, homogeneous values (between 135.2 and $139.7 \mathrm{~mm} \mathrm{day}^{-1}$ ) are obtained for the entire valley.

\section{Climate data}

To calculate $\mathrm{ET}_{\mathrm{o}}$ according to the HG method, we used data obtained from 311 stations within the study area that record maximum and minimum temperatures. These temperature stations were selected from a total of 1584 stations. The 311 selected stations each had a minimum of 15 years of complete data within the period 1970-2003 and passed a process of quality control and homogenization testing. Anomalous records were identified and 

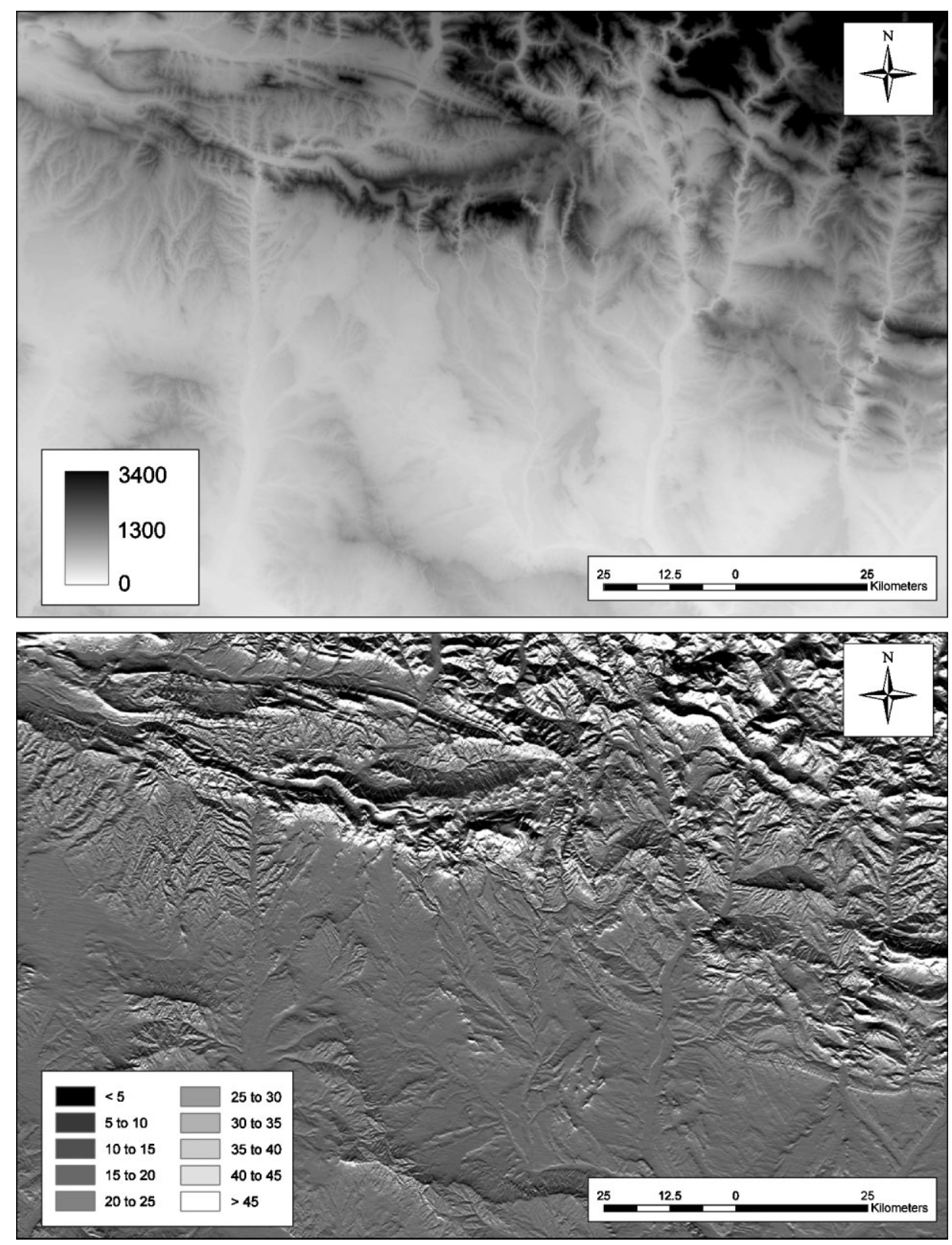

Figure 1. Digital elevation model in a sector of the Ebro valley (above). The figure showed below indicates the spatial distribution of the $R_{\mathrm{a}}\left(\mathrm{mm} \mathrm{day}^{-1}\right)$ in January over the same region.

removed using a quartile-based range statistic, in line with the method of González-Rouco et al. (2001). To guarantee the final quality of the data, we checked the homogeneity of each weather station (Lanzante, 1996; Peterson et al., 1998) against an independent reference series generated by selecting the five series whose difference series correlated best with those of the station to be tested (Peterson and Easterling, 1994). The standard normal homogeneity test (SNHT) was used to identify inhomogeneities in the temperature series (Alexandersson, 1986); calculations were performed using the software ANCLIM (Štěpánek, 2004). Average monthly maximum and minimum temperatures were calculated for the 311 selected stations.

Finally, $80 \%$ of the data were selected for interpolation, with the remaining $20 \%$ used to validate the maps.
The spatial distribution of the meteorological stations is shown in Figure 2.

\section{Spatial interpolation procedures}

In this study, we use the HG method to obtain continuous maps of $\mathrm{ET}_{\mathrm{o}}$ at a spatial resolution of $100 \mathrm{~m}$ using the following four different procedures.

(1) Modelling the maximum and minimum temperatures by means of regression-based interpolation and the $R_{\mathrm{a}}$ as a function of latitude and assuming a planar land surface, as described by Allen et al. (1998). Following this, the HG equation is applied by means of layer algebra within the GIS environment.

(2) Local calculation of $\mathrm{ET}_{\mathrm{o}}$ using $R_{\mathrm{a}}$ values calculated as a function of latitude and assuming a planar 


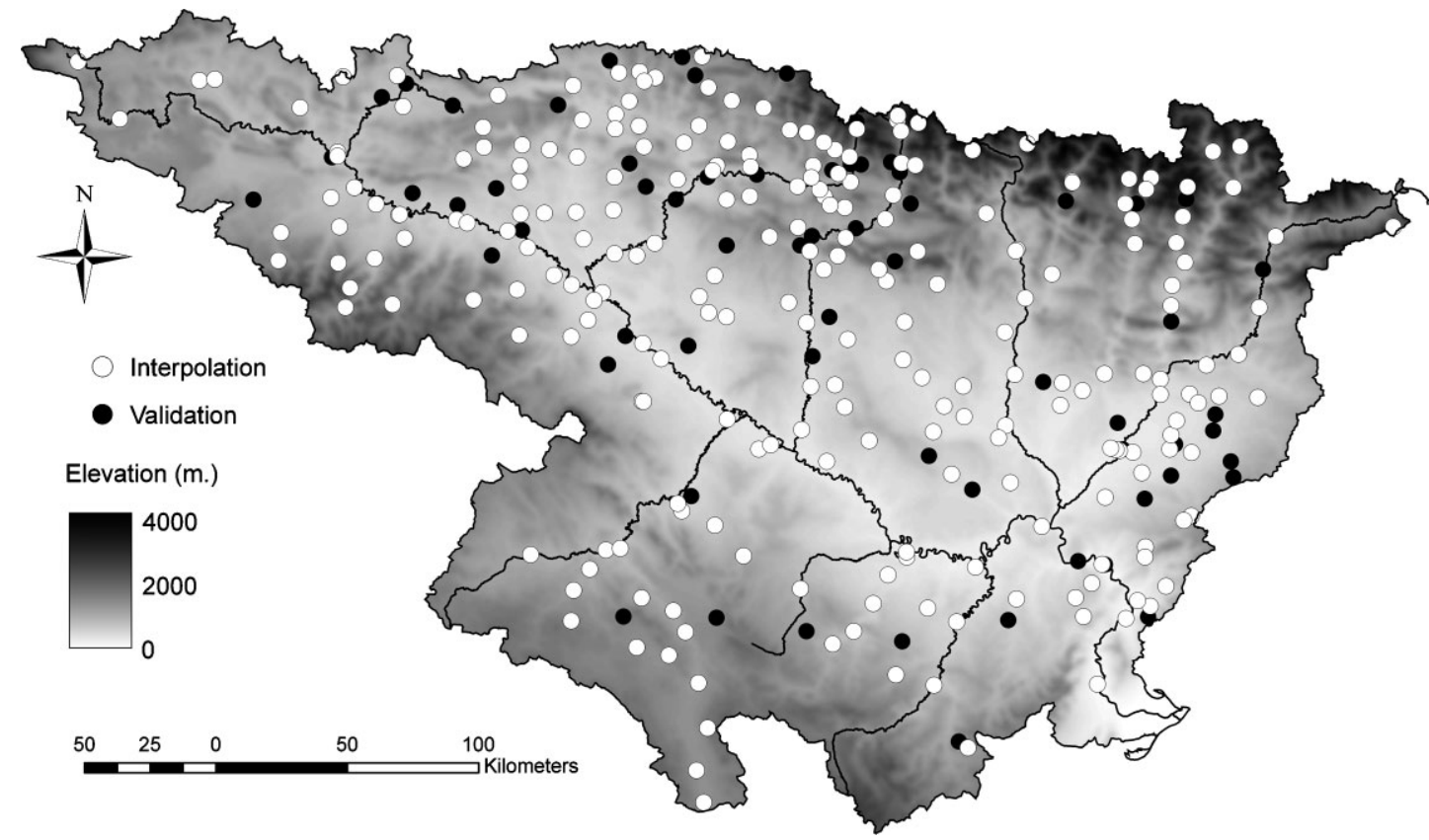

Figure 2. Location and elevation of the Ebro valley. The circles indicate the location of the weather stations used for interpolation (white) and test (black).

land surface. $\mathrm{ET}_{\mathrm{o}}$ values were then modelled using regression-based interpolation and GIS.

(3) Modelling the maximum and minimum temperatures by regression-based interpolation and $R_{\mathrm{a}}$ from a DEM and GIS. The HG equation is then applied by layer algebra within the GIS environment.

(4) Local calculation of $\mathrm{ET}_{\mathrm{o}}$, using $R_{\mathrm{a}}$ values obtained from a DEM and GIS data from the locations of the weather stations. $\mathrm{ET}_{\mathrm{o}}$ values are then modelled using regression-based interpolation and GIS.

The purpose of applying these four procedures is to investigate whether the results vary as a function of the procedure chosen to calculate $R_{\mathrm{a}}$. We also wish to determine if it is better to calculate $\mathrm{ET}_{\mathrm{o}}$ locally after modelling these values, or if we should consider the previously modelled layers of maximum and minimum temperatures for algebraic calculations within GIS.

When maps are used as inputs in a GIS operation, errors in the input propagate to the output of the operation; these errors continue to propagate when the output from one operation is used as input to an ensuing operation. Consequently, if no record is kept of the accuracy of intermediate results, it becomes extremely difficult to evaluate the accuracy of the final result (Heuvelink et al., 1989; Heuvelink, 1998; Arbia et al., 1998; Karssenberg and De Kong, 2005). In this study, we assessed the possible consequences of error propagation in calculating $\mathrm{ET}_{\mathrm{o}}$ via GIS layers by using a number of different procedures to obtain the $\mathrm{ET}_{\mathrm{o}}$ maps. This approach makes it possible to determine if uncertainties in the final prediction reflect uncertainties in the data (temperature layers) or in the model structure (models compiled from local $\mathrm{ET}_{\mathrm{o}}$ calculations).
Spatial interpolation of maximum and minimum temperatures and local $\mathrm{ET}_{\mathrm{o}}$ calculations were performed using regression-based techniques. A number of different interpolation procedures are used to obtain maps from punctual meteorological data: global, local, and geostatistics (Burrough and McDonnell, 1998), and these are widely used to map climate variables. The most widely used procedures are global methods based on regression techniques. In these methods, different geographic and topographic factors that control the spatial distribution of climate are used as independent variables (Bonacina, 1945; Tabony, 1985; Basist et al., 1994; Daly et al., 1994, 2002), and dependence models are created between the climate data and independent variables. The value of a climate variable in unsampled points is obtained according to the following equation:

$$
z(x)=b_{0}+b_{1} P_{1}+b_{2} P_{2}+\cdots+b_{n} P_{n}
$$

where $\mathrm{z}$ is the predicted value of the climate variable at point $x$.

$b_{0} \ldots b_{n}$ are the regression coefficients.

$P_{1} \ldots P_{n}$ are the values of the different independent variables at point $x$.

The main advantage of this technique is that maps are compiled not only from information from various weather stations but also from auxiliary information that describes geographic and topographic variables; this improves the accuracy and spatial detail of the resulting maps.

To map the maximum and minimum temperatures and local $\mathrm{ET}_{\mathrm{o}}$ estimates using regression-based techniques, we used independent variables at a spatial resolution 
Table I. Independent geographic and topographic variables used in the regression-based interpolation.

\begin{tabular}{|c|c|}
\hline LONG & Longitude \\
\hline LAT & Latitude \\
\hline D_MED & Distance to Mediterranean Sea \\
\hline D_BIS & Distance to Bay of Biscay \\
\hline RAD & $\begin{array}{l}\text { Annual average incoming solar radiation in } \\
\mathrm{MJ} \times \text { day }\end{array}$ \\
\hline $\operatorname{RAD}_{X}$ & $\begin{array}{l}\text { Annual average incoming solar radiation in } \\
\mathrm{MJ} \times \text { day within } x_{i} \text { where } x \text { is a radius of } 2.5 \text {, } \\
5 \text {, and } 25 \mathrm{~km}\end{array}$ \\
\hline SLO & Slope \\
\hline ELEV & Elevation in metres \\
\hline $\mathrm{ELEV}_{X}$ & $\begin{array}{l}\text { Mean elevation within } x_{i} \text {, where } x \text { is a radius } \\
\text { of } 2.5,5 \text {, and } 10 \mathrm{~km}\end{array}$ \\
\hline
\end{tabular}

of $100 \mathrm{~m}$ (Table I); however, correlation between independent variables leads to problems with colinearity. To avoid this, a forward stepwise procedure with 'probability to enter' set to 0.01 was used to select only the significant variables, as recommended by Hair et al. (1998).

The disadvantage in using this kind of method to map climate data is that the results are inexact because the predicted value of the climatic variable $z(x)$ does not coincide with the real data collected at weather stations; however, the error is known at each point and procedures can be performed to correct for the error. The residual (difference between the climatic variable measured at a weather station and that predicted by the model) is commonly obtained and interpolated over the entire territory using local techniques. This procedure has been used by Ninyerola et al. (2000); Agnew and Palutikof (2000); Brown and Comrie (2002), and Beguería and Vicente-Serrano (2006), among others. In the present paper, we use a method of splines with tension (Mitasova and Mitas, 1993) to interpolate the residuals. This method has proved to be more suitable than other local techniques such as inverse-distance weighting to map residuals in the central Ebro valley (Vicente-Serrano et al., 2003).

\section{Validation of the maps}

To validate the maps, we used the data from the $20 \%$ of weather stations selected randomly and reserved for subsequent tests, and employed a set of accuracy/error statistics (Willmott, 1982): mean bias error (MBE), which indicates the average over- or under-interpolation and mean absolute error (MAE), which is a measure of the average error of the interpolation. We did not use the most widely used error statistic, the root mean square error (RMSE), because Willmott and Matsuura (2005, 2006) provided evidence that the RMSE varies with variability in the squared errors and that it is impossible to discern the degree to which the RMSE reflects average error and to what extent it reflects variability in the distribution of squared errors.

We also used a relative and bounded measure to assess map quality. The agreement index ([D]; Willmott, 1981) retains mean information and does not amplify outliers.
Table II. Error measures used to assess the validity of the ET maps.

\begin{tabular}{ll}
\hline & Definitions: \\
& $N$ : number of observations \\
& $O$ : Observed value \\
& $O$ : mean of observed values \\
& $P$ : Predicted value \\
& $P_{i}^{\prime}=P_{i}-\bar{O}$ \\
& $O_{i}^{\prime}=O_{i}-\bar{O}$ \\
& $M B E=N^{-1} \sum_{i=1}^{N}\left(P_{i}-O_{i}\right)$ \\
MBE (mean bias error) & $M A E=N^{-1} \sum_{i=1}^{N}\left|P_{i}-O_{i}\right|$ \\
MAE (mean absolute error) & \\
& \\
D & $D=1-\frac{\sum_{i=1}^{N}\left(P_{i}-O_{i}\right)^{2}}{\sum_{i=1}^{N}\left(\left|P_{i}^{\prime}\right|+\left|O_{i}^{\prime}\right|\right)^{2}}$ \\
\hline
\end{tabular}

It also scales with the magnitude of variables, which enables comparison of the different monthly maps of $\mathrm{ET}_{\mathrm{o}}$ independently of differences in the magnitude and range of the variable for each month. Table II provides the formulations of error measures used in this study.

\section{RESULTS}

Comparison of $E T_{\mathrm{o}}$ values determined using $R_{\mathrm{a}}$ calculated from a plane and that calculated from a DTM and GIS modelling

Figure 3 shows the relationship between $\mathrm{ET}_{\mathrm{o}}$ obtained for the sites of weather stations using the $\mathrm{HG}$ method and values determined according to the following two procedures for calculating $R_{\mathrm{a}}$ : (1) assuming a planar surface and only as a function of latitude, as described by Allen et al. (1998) and (2) by means of a DTM and GIS, following the method of Pons (1996).

The results of this analysis indicate that, from April to August, there are very close and linear relationships between both sets of $\mathrm{ET}_{\mathrm{o}}$ calculations, although in some cases $\mathrm{ET}_{\mathrm{o}}$ is lower for the procedure in which $R_{\mathrm{a}}$ is calculated from a DTM and GIS. For the period September to March, the relationship is weaker, coinciding with the months in which the magnitude of $\mathrm{ET}_{\mathrm{o}}$ is low.

Table III provides R-Pearson statistics for monthly estimates derived from the two contrasting methods. There is a good agreement between the two sets of estimates for the period April to August, with $R$ values in excess of 0.9 . In contrast, $R$ values for winter months are much lower. MAE and MBE statistics show similar values in the different months. Nevertheless, the magnitude and the spatial range of the PET are much lower in winter (e.g. December: 5-45) than in summer months (e.g. July: 100-220). Therefore, although absolute differences are similar between summer and winter, the relative differences are more important in winter months.

These results indirectly indicate the different roles of the variables involved in the $\mathrm{ET}_{\mathrm{o}}$ calculation according 

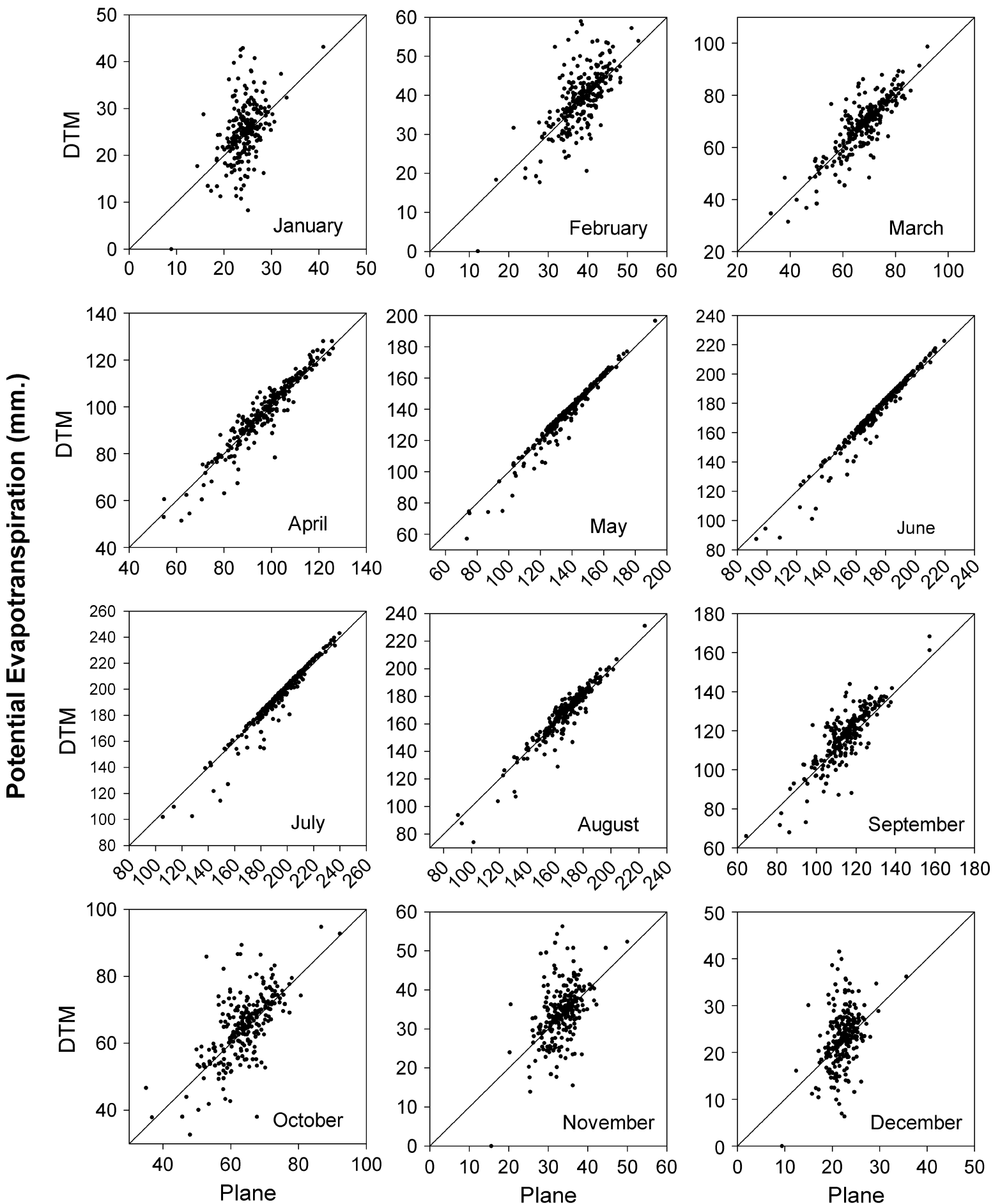

Potential Evapotranspiration (mm.)

Figure 3. Monthly relationships between the $\mathrm{ET}_{\mathrm{o}}$ calculated for the sites of weather stations by means of the HG method following two procedures for calculating the $R_{\mathrm{a}}$ : assuming a planar surface and only as a function of the latitude and by means of a DTM and GIS.

to the HG equation. During the summer months, the sun is near-perpendicular to the ground surface and most areas receive high values of solar radiation. In contrast, during winter the oblique angle of the sun enhances the shadowing effect and $R_{\mathrm{a}}$ distribution is more spatially heterogeneous than during summer (see Figure 1). Therefore, during summer only a small number of weather stations located upon north-facing slopes show lower $\mathrm{ET}_{\mathrm{o}}$ values for $R_{\mathrm{a}}$ calculated from a DTM and GIS data than for values calculated assuming a planar surface. During winter, spatial differences in $\mathrm{ET}_{\mathrm{o}}$ values are noticeable between north-facing and south-facing slopes. In contrast, the range in $R_{\mathrm{a}}$ estimates based only on latitude is very low throughout the year, which explains the poor agreement between the two sets of $\mathrm{ET}_{\mathrm{o}}$ estimates. Therefore, the act of excluding relief from 
$R_{\mathrm{a}}$ calculations introduces important differences during winter months. These differences have a noticeable effect on the final reliability of the $\mathrm{ET}_{\mathrm{o}}$ estimates, with $\mathrm{ET}_{\mathrm{o}}$ estimates derived from $R_{\mathrm{a}}$ calculated using a DTM and GIS techniques, which take into account topographic diversity, being more realistic.

$E T_{\mathrm{O}}$ maps compiled from $R_{\mathrm{a}}$ values calculated assuming a planar surface and as a function of latitude

$E T_{\mathrm{O}}$ calculations from distributed data of maximum and minimum temperatures and layer algebra within the GIS environment. One of the main problems in obtaining reliable estimations of $\mathrm{ET}_{0}$ is the temperature mapping (maximum and minimum). Table IV shows the coefficients of determination $\left(R^{2}\right)$ of the models used to obtain continuous layers of maximum and minimum temperatures at $100-\mathrm{m}$ grid size. The models are obtained from variables listed in Table I. Table IV also shows the MBE, MAE and $\mathrm{D}$ error measures. These error measures were calculated before correction of the local model using residual interpolation (see section on Spatial Interpolation Procedures). In general, the model performance is slightly better for maximum rather than minimum temperatures and also in summer rather than winter. In any case, the coefficients of determination are greater than 0.60 for all the different monthly models. The error estimates demonstrate the reliability of the maps after the residual corrections. The MAE varies between $0.63^{\circ} \mathrm{C}$ for minimum temperatures in January and $1.10^{\circ} \mathrm{C}$ for minimum temperatures in August. The D statistic, which enables a comparison of the goodness of the monthly maps independently of differences in magnitude, is around 0.90 for most months, and is above 0.84 for all winter months. This indicates the high reliability of the created layers when compared with independent temperature values.

Table III. R-Pearson statistics for monthly estimates derived from the $\mathrm{ET}_{\mathrm{o}}$ calculated in the sites of weather stations by means of the HG method following two procedures for calculating $R_{\mathrm{a}}$ : (1) assuming a planar surface and only as a function of latitude and (2) by means of a DTM and GIS. Also, mean absolute error (MAE) in mm (and mean bias error (MBE) are included).

\begin{tabular}{lccc}
\hline Month & R-Pearson & MAE & MBE \\
\hline January & 0.48 & 3.8 & -0.7 \\
February & 0.69 & 3.9 & -0.8 \\
March & 0.85 & 4.3 & -0.8 \\
April & 0.95 & 3.3 & -0.6 \\
May & 0.98 & 2.7 & -0.3 \\
June & 0.98 & 3.1 & -0.1 \\
July & 0.97 & 3.4 & -0.2 \\
August & 0.95 & 4.2 & -0.5 \\
September & 0.85 & 6.2 & -2.7 \\
October & 0.69 & 5.4 & -1.0 \\
November & 0.48 & 4.5 & -0.8 \\
December & 0.40 & 3.9 & -0.7 \\
\hline
\end{tabular}

Table IV. Results of the monthly maximum and minimum temperature models by means of regression-based interpolation. MBE: mean bias error, MAE: mean absolute error, D: agreement index (Willmott, 1981).

\begin{tabular}{|c|c|c|c|c|c|c|c|c|}
\hline \multirow[t]{2}{*}{ Month } & \multicolumn{4}{|c|}{$\begin{array}{l}\text { Maximum } \\
\text { temperature }\end{array}$} & \multicolumn{4}{|c|}{$\begin{array}{l}\text { Minimum } \\
\text { temperature }\end{array}$} \\
\hline & $R^{2}$ & MBE & MAE & D & $R^{2}$ & MBE & MAE & D \\
\hline January & 0.65 & 0.07 & 0.81 & 0.85 & 0.61 & 0.07 & 0.63 & 0.91 \\
\hline February & 0.81 & -0.04 & 0.75 & 0.93 & 0.63 & 0.01 & 0.69 & 0.90 \\
\hline March & 0.81 & -0.11 & 0.90 & 0.93 & 0.67 & 0.03 & 0.94 & 0.89 \\
\hline April & 0.86 & -0.13 & 0.87 & 0.95 & 0.77 & -0.06 & 0.83 & 0.92 \\
\hline May & 0.85 & -0.14 & 0.96 & 0.95 & 0.78 & -0.12 & 0.92 & 0.91 \\
\hline June & 0.82 & -0.08 & 0.94 & 0.95 & 0.81 & -0.12 & 0.86 & 0.93 \\
\hline July & 0.79 & -0.18 & 1.01 & 0.95 & 0.79 & -0.16 & 1.03 & 0.92 \\
\hline August & 0.79 & -0.04 & 1.08 & 0.93 & 0.79 & -0.17 & 1.10 & 0.92 \\
\hline September & 0.82 & -0.06 & 1.02 & 0.93 & 0.77 & -0.12 & 1.07 & 0.91 \\
\hline October & 0.85 & -0.05 & 0.95 & 0.92 & 0.73 & -0.18 & 1.02 & 0.89 \\
\hline November & 0.75 & 0.00 & 0.82 & 0.88 & 0.65 & -0.10 & 0.91 & 0.89 \\
\hline December & 0.60 & 0.00 & 0.79 & 0.84 & 0.61 & 0.00 & 0.76 & 0.90 \\
\hline
\end{tabular}

Figure 4 shows obtained temperature maps for April. Both maps in the figure show spatial variations in temperature in the Ebro valley, within which patterns of relief play a major role. Lower temperatures are recorded in the north (Pyrenean Chain) and parts of the south (Iberian Range), and the maps provide significant detail of local differences between valleys and adjacent mountains. In the central part of the valley, temperatures are higher than in the mountains and spatial variation in temperature is low as a consequence of the relatively simple topography. However, it is possible to identify differences in temperature within the central valley area that reflect the effect of tertiary relief and the Catalan Coast mountain chain, as well as the commonly observed thermal inversion that characterises certain areas (Braun-Blanquet and Bolos, 1957). Influences of the Mediterranean/Atlantic and continental influences are also captured by the models. This explains the higher temperatures to the east, in a region surrounded by different mountain chains, and in areas closest to the Mediterranean Sea.

Figure 5 shows $\mathrm{ET}_{\mathrm{o}}$ maps for January and July, representative of winter and summer months, respectively. The maps were compiled by applying the HG equation via algebraic calculations in GIS using temperature maps as inputs and a layer of $R_{\mathrm{a}}$ calculated as a function of latitude.

Local $E T_{\mathrm{O}}$ calculation and modelling using regressionbased interpolation and GIS. Table V shows the coefficients of determination and variables used in the models of $\mathrm{ET}_{\mathrm{o}}$ obtained from local estimates. The coefficients of determination $\left(R^{2}\right)$ are generally slightly lower than those calculated when modelling maximum and minimum temperatures; this indicates greater difficulty in directly obtaining $\mathrm{ET}_{\mathrm{o}}$ models than using the maximum and maximum temperature models. In general, values of $R^{2}$ are higher for spring and autumn months than for 

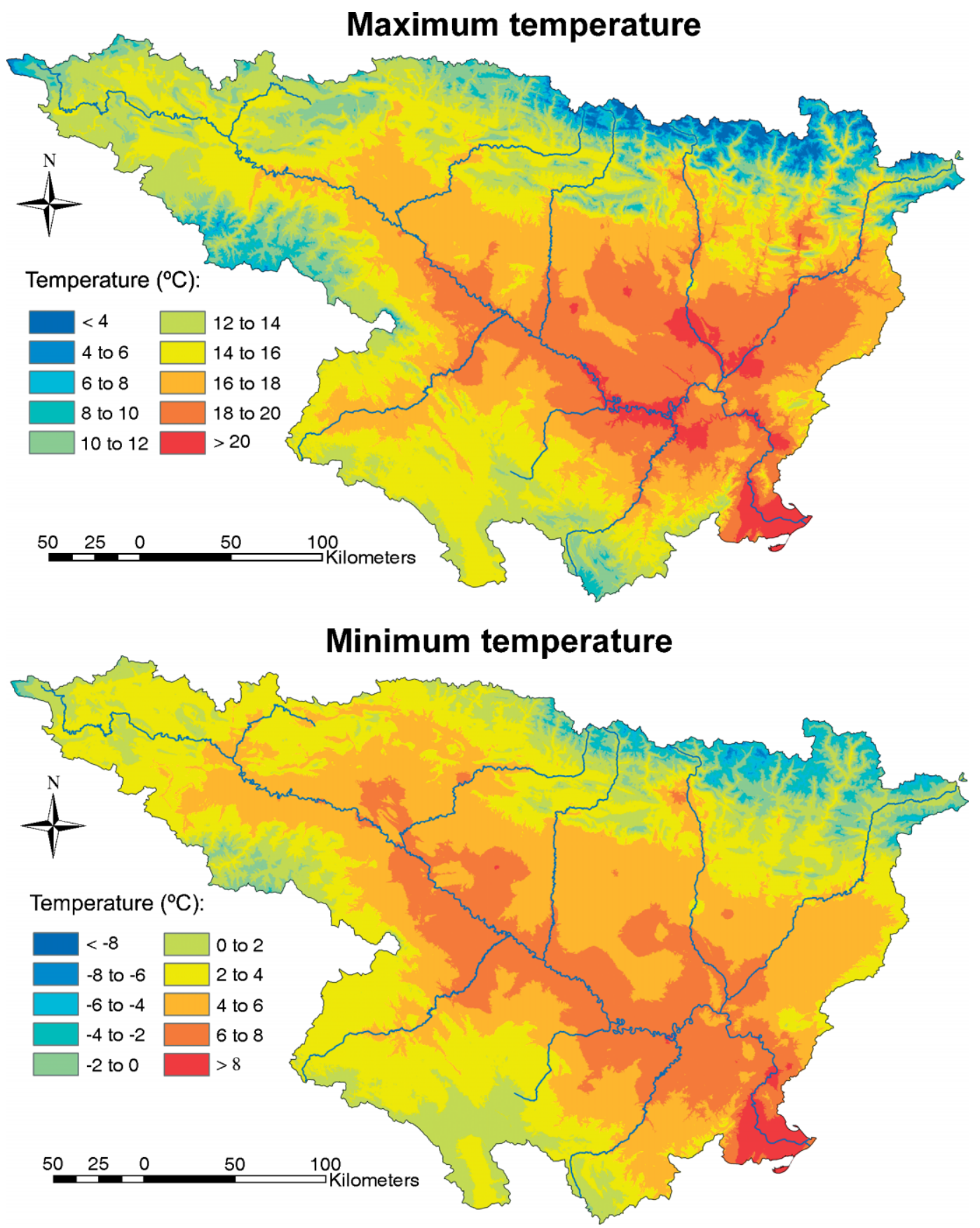

Figure 4. Two examples of monthly maximum and minimum temperature maps (April) obtained from regression-based interpolation.

winter and summer, with lowest $R^{2}$ values for December (0.52) and August (0.54).

Although incoming solar radiation was included as a candidate independent variable, this variable was not included in the models for any month. In general, elevation, latitude, and distance to Bay of Biscay are the most important variables, and as such are included in the majority of the monthly models.

$E T_{\mathrm{O}}$ maps compiled from $R_{\mathrm{a}}$ modelled using a DTM and GIS modelling

$E T_{0}$ maps from maximum and minimum temperature layers and GIS algebraic calculations. Figure 6 shows $\mathrm{ET}_{\mathrm{o}}$ maps for January and July obtained from the HG equation and using modelled maximum and minimum temperature maps and $R_{\mathrm{a}}$ layers obtained from a DTM and GIS modelling. The maps show slight differences to previous maps where $R_{\mathrm{a}}$ was calculated assuming a planar surface. The main differences are observed for maps for months in winter, autumn, and spring. The map for January (Figure 6) is an excellent demonstration of the importance of local features in terms of the complexity of relief. There are very important spatial differences in temperature between neighbouring areas, mainly between the northern and southern slopes of the main mountain chains, for which the differences can be in excess of $40 \mathrm{~mm}$ month $^{-1}$. In contrast, the $\mathrm{ET}_{\mathrm{o}}$ maps obtained from $R_{\mathrm{a}}$ calculated solely from 

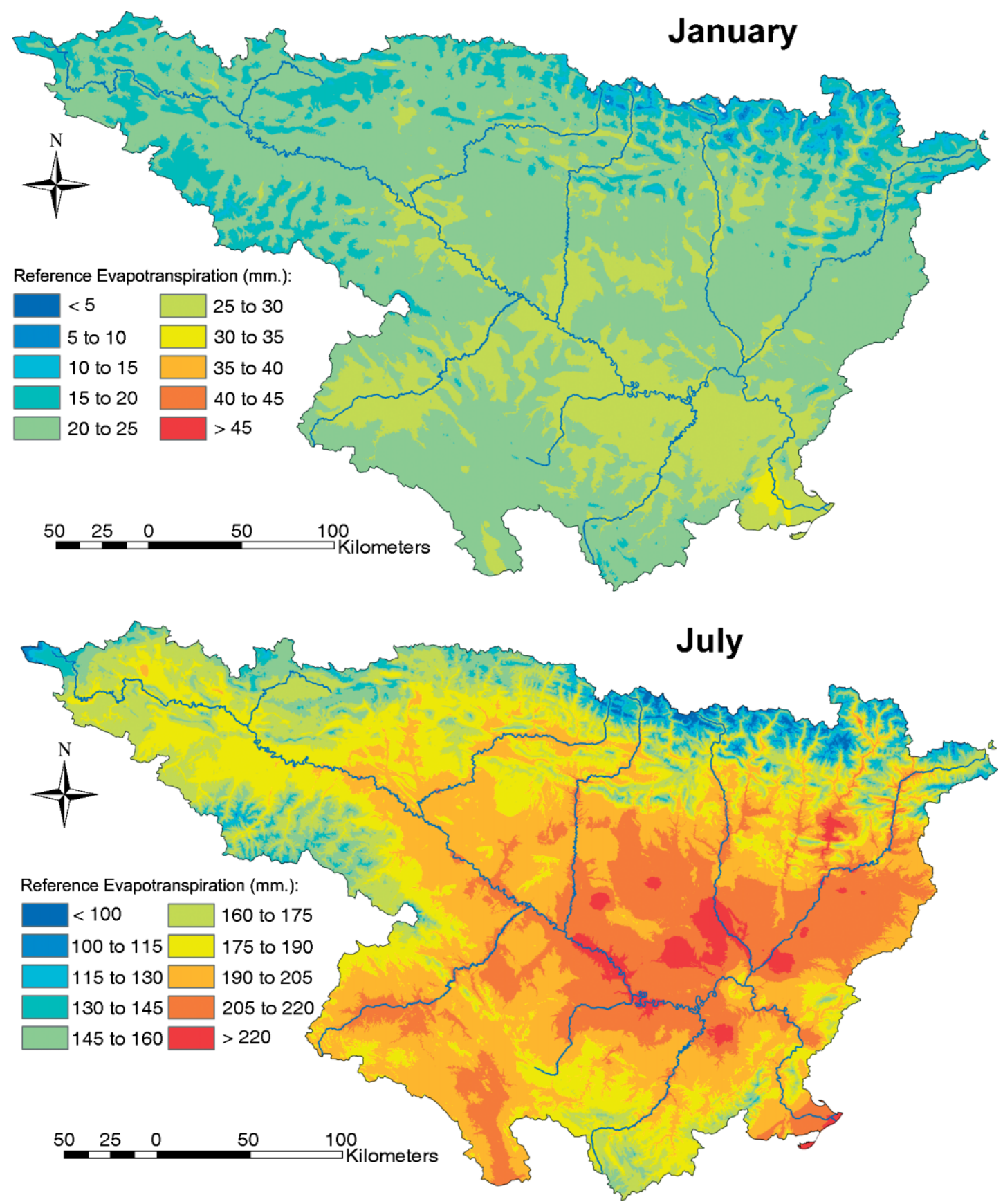

Figure 5. Reference evapotranspiration $\left(\mathrm{ET}_{\mathrm{o}}\right)$ maps of January and July obtained from spatial models via algebraic calculations in GIS using temperature maps as inputs and a layer of $R_{\mathrm{a}}$ calculated as a function of latitude.

latitude (Figure 5) do not show these spatial differences. The spatial differences are less evident during summer because of the lesser influence of relief on the spatial distribution of $R_{\mathrm{a}}$ at this time of year.

Local $E T_{\mathrm{O}}$ calculation and modelling using regressionbased interpolation and GIS. Table VI shows the coefficients of determination $\left(R^{2}\right)$ and variables used in the models used to map $\mathrm{ET}_{\mathrm{o}}$ calculated at the sites of weather stations according to the $\mathrm{HG}$ method. $R^{2}$ values are considerably higher than those obtained from the models in which $\mathrm{ET}_{\mathrm{o}}$ was calculated from $R_{\mathrm{a}}$ modelled as a planar surface (Table V). The main differences are evident in the winter months: the previous procedure produced $R^{2}$ values between 0.5 and 0.65 , whereas the use of $R_{\text {a }}$ modelled using a DTM results in values up to 0.7 . These differences in $R^{2}$ are lower for the months between March and October, but higher $R^{2}$ values are always obtained for $\mathrm{ET}_{\mathrm{o}}$ calculations in which $R_{\mathrm{a}}$ is calculated using a DTM.

It is interesting to note that, with the exception of June and July (months in which the spatial distribution of the $R_{\mathrm{a}}$ is more homogeneous), incoming solar radiation is included in all the models. The models also generally consider the elevation within a radius of $2.5 \mathrm{~km}$ of the site and the distance to the Bay of Biscay. 
Table V. Coefficients of determination and variables used in the monthly models of $\mathrm{ET}_{\mathrm{o}}\left(R_{\mathrm{a}}\right.$ calculated assuming a planar surface).

\begin{tabular}{|c|c|c|}
\hline Months & $R^{2}$ & Variables \\
\hline January & 0.59 & LAT, ELEV, ELEV ${ }_{10}$, ELEV $_{5}$ \\
\hline February & 0.75 & $\mathrm{LAT}$ ELEV, $\mathrm{ELEV}_{10}, \mathrm{ELEV}_{5}, \mathrm{D}_{-} \mathrm{BIS}$ \\
\hline March & 0.73 & ELEV, $\mathrm{ELEV}_{10}, \mathrm{ELEV}_{5}, \mathrm{D}_{-} \mathrm{BIS}$ \\
\hline April & 0.77 & ELEV, D_BIS \\
\hline May & 0.75 & ELEV, D_BIS \\
\hline June & 0.68 & ELEV, D_BIS, SLOPE \\
\hline July & 0.60 & $\mathrm{ELEV}_{10}, \mathrm{ELEV}_{5}, \mathrm{D}_{-} \mathrm{BIS}$ \\
\hline August & 0.54 & ELEV, D_BIS \\
\hline September & 0.62 & $\mathrm{LAT}, \mathrm{ELEV}_{10}, \mathrm{ELEV}_{5}, \mathrm{D} \_\mathrm{BIS}$ \\
\hline October & 0.70 & $\mathrm{LAT}, \mathrm{ELEV}, \mathrm{ELEV}_{10}, \mathrm{ELEV}_{5}, \mathrm{D}_{-} \mathrm{BIS}$ \\
\hline November & 0.63 & LAT, ELEV, ELEV $10, \mathrm{ELEV}_{5}, \mathrm{D}_{-} \mathrm{BIS}$ \\
\hline December & 0.52 & LAT, ELEV, ELEV 10, ELEV $_{5}$ \\
\hline
\end{tabular}

Table VI. Coefficients of determination and variables used in the monthly models of $\mathrm{ET}_{\mathrm{o}}\left(R_{\mathrm{a}}\right.$ modelled using a DTM).

\begin{tabular}{|c|c|c|}
\hline Months & $R^{2}$ & Variables \\
\hline January & 0.72 & $\begin{array}{l}\text { LAT, ELEV, ELEV } \\
10, \mathrm{ELEV}_{5} \text {, } \\
\text { RAD, RAD } 2.5\end{array}$ \\
\hline February & 0.77 & $\begin{array}{l}\text { ELEV }_{2.5}, \text { D_BIS, D_MED, } \\
\text { RAD, RAD } 2.5\end{array}$ \\
\hline March & 0.75 & $\begin{array}{l}\text { ELEV }_{2.5}, \text { D_BIS, SLOPE, } \\
\text { D_MED, RAD }\end{array}$ \\
\hline April & 0.79 & $\begin{array}{l}\text { ELEV }_{2.5}, \text { D_BIS, SLOPE, } \\
\text { RAD }\end{array}$ \\
\hline May & 0.78 & $\begin{array}{l}\text { ELEV }_{2.5}, \text { D_BIS, SLOPE, } \\
\text { RAD }\end{array}$ \\
\hline June & 0.73 & ELEV $_{2.5}$, D_BIS, SLOPE \\
\hline July & 0.65 & ELEV $_{2.5}$, D_BIS, SLOPE \\
\hline August & 0.62 & $\begin{array}{l}\text { ELEV }_{2.5}, \text { D_BIS, SLOPE, } \\
\text { RAD }\end{array}$ \\
\hline September & 0.65 & $\begin{array}{l}\text { ELEV }_{2.5}, \text { D_BIS, SLOPE, } \\
\text { D_MED, RAD }\end{array}$ \\
\hline October & 0.72 & $\begin{array}{l}\text { ELEV }_{2.5}, \text { D_BIS, SLOPE, } \\
\text { D_MED, RAD }\end{array}$ \\
\hline November & 0.72 & $\begin{array}{l}\text { ELEV }_{2.5}, \text { D_BIS, SLOPE, } \\
\text { D_MED, RAD, RAD } 2.5\end{array}$ \\
\hline December & 0.74 & $\begin{array}{l}\text { ELEV }_{5}, \text { SLOPE, ELEV, LAT, } \text { RAD, RAD } 2.5, \text { ELEV }_{10}\end{array}$ \\
\hline
\end{tabular}

\section{VALIDATION OF THE OBTAINED MAPS}

We validated the different monthly maps using $20 \%$ of the weather stations reserved for this purpose. As the $\mathrm{ET}_{\mathrm{o}}$ values calculated using $R_{\mathrm{a}}$ obtained from the two different procedures (planar surface and a DTM) are not comparable (see section on Comparison of $\mathrm{ET}_{\mathrm{o}}$ values determined using $R_{\mathrm{a}}$ calculated from a plane and that calculated from a DTM and GIS modelling), validation was carried out independently for each type of $\mathrm{ET}_{\mathrm{o}}$ estimate by calculating $\mathrm{ET}_{\mathrm{o}}$ values according to both procedures for those weather stations reserved for validation.
Table VII. Error/validation estimates for the $\mathrm{ET}_{\mathrm{o}}$ maps in the case that $R_{\mathrm{a}}$ is obtained as a function of the latitude.

\begin{tabular}{|c|c|c|c|c|c|c|}
\hline \multirow[t]{2}{*}{ Months } & \multicolumn{3}{|c|}{$\begin{array}{l}\text { GIS algebraic } \\
\text { calculations }\end{array}$} & \multicolumn{3}{|c|}{$\begin{array}{l}\text { Local } \mathrm{ET}_{\mathrm{o}} \text { calculation } \\
\text { and modelling }\end{array}$} \\
\hline & MBE & MAE & D & MBE & MAE & $\mathrm{D}$ \\
\hline January & 0.09 & 1.85 & 0.75 & 0.12 & 1.76 & 0.80 \\
\hline February & -0.09 & 2.61 & 0.81 & 3.54 & 4.11 & 0.72 \\
\hline March & -0.45 & 5.26 & 0.81 & -0.25 & 5.28 & 0.81 \\
\hline April & -0.51 & 6.94 & 0.85 & 2.75 & 7.63 & 0.85 \\
\hline May & -0.45 & 9.91 & 0.83 & -0.42 & 10.00 & 0.83 \\
\hline June & 0.06 & 10.77 & 0.83 & 4.73 & 12.31 & 0.81 \\
\hline July & -0.74 & 11.55 & 0.84 & -0.44 & 12.89 & 0.80 \\
\hline August & 0.56 & 10.96 & 0.76 & 0.12 & 10.13 & 0.81 \\
\hline September & 0.14 & 7.47 & 0.76 & 3.88 & 8.61 & 0.72 \\
\hline October & 0.31 & 4.95 & 0.77 & 0.13 & 4.95 & 0.79 \\
\hline November & 0.19 & 2.37 & 0.76 & 1.22 & 2.38 & 0.79 \\
\hline December & 0.05 & 1.67 & 0.69 & 0.11 & 1.50 & 0.78 \\
\hline
\end{tabular}

Table VII shows the error estimates obtained for the $\mathrm{ET}_{\mathrm{o}}$ maps in the case that $R_{\mathrm{a}}$ is obtained as a function of latitude. Error measures are shown for (1) those maps obtained from the maximum and minimum temperature layers and GIS algebraic calculations and (2) those maps derived from local $\mathrm{ET}_{\mathrm{o}}$ and later modelling using regression-based interpolation and GIS. The results show a similar accuracy for both procedures, but results are generally better for those maps obtained via GIS algebraic calculations from the maximum and minimum temperature layers. The layers of maximum and minimum temperature show better $R^{2}$ values than those obtained from the modelling of local $\mathrm{ET}_{\mathrm{o}}$ calculations. This indicates that the use of GIS algebraic methods to calculate $\mathrm{ET}_{\mathrm{o}}$ by means of input variables, which can be modelled more easily than local $\mathrm{ET}_{0}$ values, may be a better approach, although some propagation errors arose during the calculations. The occurrence of these errors, and the inferior error measures obtained from this procedure used to calculate $\mathrm{ET}_{\mathrm{o}}$, suggests that, although error propagation is avoided, modelling of $\mathrm{ET}_{\mathrm{o}}$ is more difficult than modelling of the input temperature variables, and greater errors occur in the maps.

Table VIII shows the results obtained from the same two procedures (local estimates and layer algebra), but this time using $R_{\mathrm{a}}$ obtained from a DTM. In this case, error estimates are again lower for maps obtained from GIS algebraic calculations than those obtained from local $\mathrm{ET}_{\mathrm{o}}$ calculations and modelling. The MAE is noticeably lower for the first procedure, especially during summer months. The differences in error measures in the two procedures are greater than those resulting from $R_{\mathrm{a}}$ obtained as a function of latitude. The MBE and MAE measures show little difference in relation to the maps in which $R_{\mathrm{a}}$ was obtained as a function of latitude. Nevertheless, the D shows values that are noticeably higher: in excess of 0.84 for the monthly maps obtained using GIS algebraic calculations and commonly above 0.90 . For local $\mathrm{ET}_{\mathrm{o}}$ calculations and 

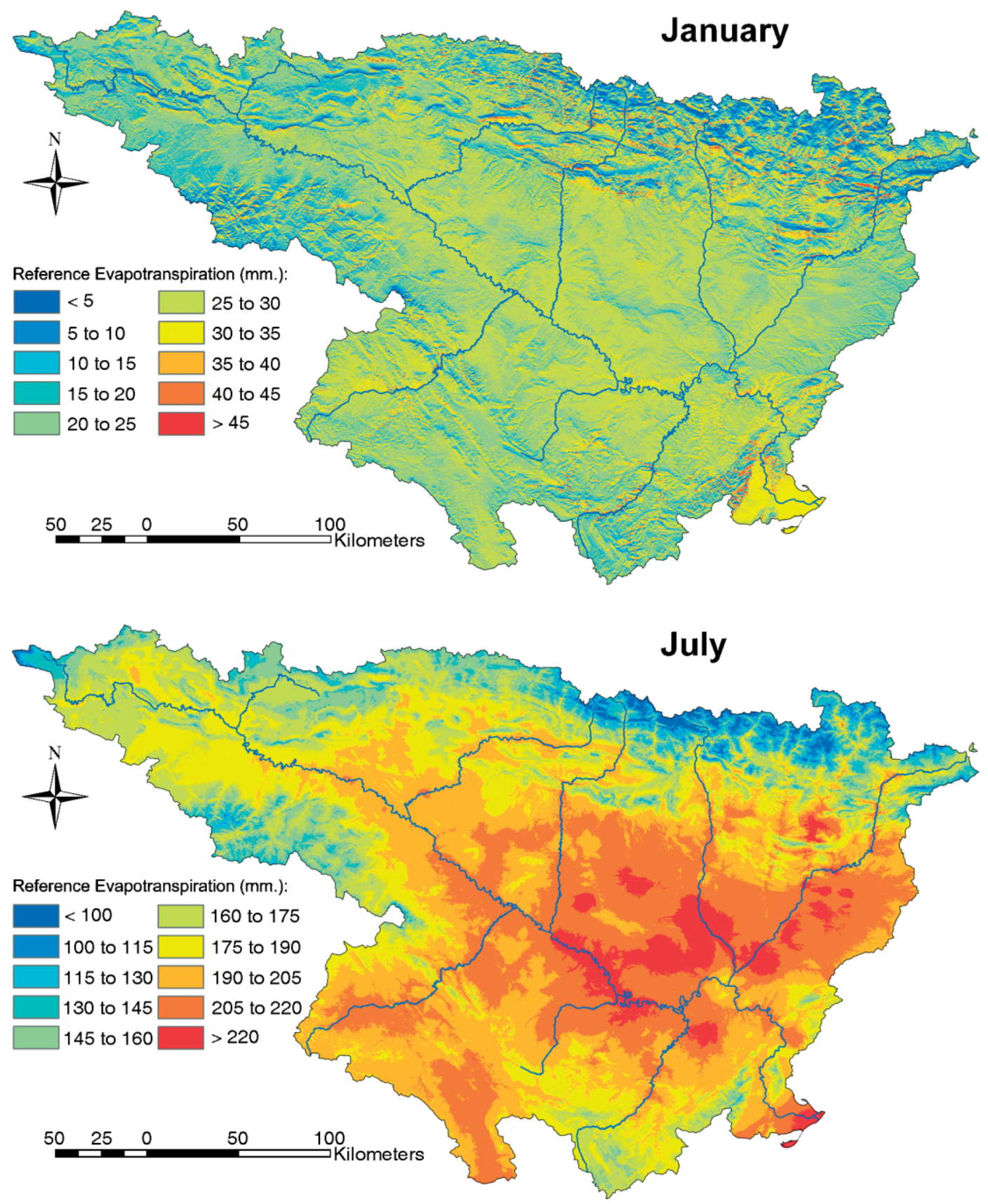

Figure 6. Reference evapotranspiration ( $\left(\mathrm{ET}_{\mathrm{o}}\right)$ maps of January and July obtained from spatial models via algebraic calculations in GIS using temperature maps as inputs and a layer of $R_{\mathrm{a}}$ obtained from a DTM and GIS modelling.

later modelling, the $\mathrm{D}$ values are also higher than those listed in Table VII. This observation also indicates that the use of $R_{\mathrm{a}}$ estimates obtained using a DEM improves the final $\mathrm{ET}_{\mathrm{o}}$ and enhances $\mathrm{ET}_{\mathrm{o}}$ modelling.

\section{DISCUSSION AND CONCLUSIONS}

This paper demonstrates the great potential of the statistical modelling of climate variables when used in tandem with GIS to map $\mathrm{ET}_{\mathrm{o}}$, a variable that is important in many environmental processes and is very useful for the management of agriculture, ecology, and water resources (Doorenbos and Pruitt, 1977; Pereira et al., 1999).
We used the HG method to map $\mathrm{ET}_{\mathrm{o}}$ because, to create reliable maps, it is necessary to have a dense database of the climatic information used in the calculations. Although the most accurate method is the one that is physically based on the PM equation, the large number of parameters required in this calculation means that it is not possible to obtain the dense spatial database of $\mathrm{ET}_{\mathrm{o}}$ calculations needed to produce reliable maps. In addition, several authors have demonstrated that, for $\mathrm{ET}_{\mathrm{o}}$ estimates for periods longer than 1 week, the HG method provides similar results to those obtained using the PM equation (e.g. Droogers and Allen, 2002; Hargreaves and Allen, 2003). For the Ebro valley, Spain, estimates derived from the HG method provide very similar results to those of the 
Table VIII. Error/validation estimates for the $\mathrm{ET}_{\mathrm{o}}$ maps in the case $R_{\mathrm{a}}$ is obtained from a DTM and GIS.

\begin{tabular}{|c|c|c|c|c|c|c|}
\hline & \multicolumn{3}{|c|}{$\begin{array}{l}\text { GIS algebraic } \\
\text { calculations }\end{array}$} & \multicolumn{3}{|c|}{$\begin{array}{c}\text { Local }_{\mathrm{ET}_{\mathrm{o}} \text { calculation }} \\
\text { and modelling }\end{array}$} \\
\hline & MBE & MAE & $\mathrm{D}$ & MBE & MAE & $\mathrm{D}$ \\
\hline January & -0.09 & 1.79 & 0.97 & 0.11 & 3.02 & 0.92 \\
\hline February & -0.22 & 2.65 & 0.95 & 3.60 & 4.86 & 0.89 \\
\hline March & -0.54 & 5.28 & 0.91 & -0.30 & 5.81 & 0.90 \\
\hline April & -0.54 & 6.98 & 0.89 & 2.16 & 8.03 & 0.86 \\
\hline May & -0.43 & 9.88 & 0.87 & -1.45 & 10.94 & 0.81 \\
\hline June & 0.12 & 10.77 & 0.86 & 3.24 & 13.56 & 0.78 \\
\hline July & -0.65 & 11.57 & 0.87 & -2.94 & 13.77 & 0.80 \\
\hline August & 0.57 & 10.84 & 0.84 & 0.02 & 11.70 & 0.82 \\
\hline September & 0.15 & 7.65 & 0.89 & 2.38 & 9.26 & 0.85 \\
\hline October & 0.18 & 4.97 & 0.93 & -0.92 & 5.96 & 0.91 \\
\hline November & 0.08 & 2.42 & 0.96 & 0.73 & 3.79 & 0.91 \\
\hline December & -0.06 & 1.58 & 0.97 & -0.06 & 2.90 & 0.92 \\
\hline
\end{tabular}

PM equation for varied geographic and climatic locations (Martínez-Cob, 2002; Martínez-Cob and Tejero-Yuste, 2004; López-Moreno et al., 2003).

We have demonstrated that $\mathrm{ET}_{\mathrm{o}}$ estimates derived from the HG method change noticeably if the value of $R_{\mathrm{a}}$ used in the $\mathrm{ET}_{\mathrm{o}}$ calculation is modelled assuming a planar surface and solely as a function of latitude (Allen et al., 1998) compared to $R_{\mathrm{a}}$ modelled using a DTM and GIS. The main relative differences between these two approaches occur during the winter months, for which there is poor agreement between the two sets of $\mathrm{ET}_{\mathrm{o}}$ calculations.

In agronomic studies, calculations of $\mathrm{ET}_{\mathrm{o}}$ following the $\mathrm{HG}$ equation are generally performed using values of $R_{\mathrm{a}}$ calculated according to the method described by Allen et al. (1998), which does not take relief into account. The usefulness of this approach might not be important for irrigation purposes because irrigated lands are usually located within flat terrain in which relief does not significantly affect $R_{\mathrm{a}}$ estimates; however, for highresolution maps used for ecological and water resources management, spatial variations in relief are commonly very important and significantly affect the values of $R_{\mathrm{a}}$ estimates. Therefore, in the mountainous areas of the Ebro valley the spatial differences of vegetation cover and the rates of vegetation succession after farmland abandonment are mainly determined by exposure, which controls the incoming $R_{\mathrm{a}}$ (Lasanta et al., 2005). This stresses the high importance of including local relief features when calculating the $\mathrm{ET}_{\mathrm{o}}$.

Most previous studies involving mapping $\mathrm{ET}_{\mathrm{o}}$ at a regional scale fail to take into account the influence of topography on spatial variations in $\mathrm{ET}_{\mathrm{o}}$. In a complex terrain, spatial variations in radiation flux are especially dependant on the geometry of the terrain, and this has a significant affect on local $\mathrm{ET}_{\mathrm{o}}$ values. Häntzschel et al. (2005) showed for a small region in Germany that $\mathrm{ET}_{\mathrm{o}}$ values for southeast-facing and west-facing slopes differ by more than $100 \%$ as a consequence of topographyrelated modulation of $R_{\mathrm{a}}$.

We have demonstrated that maps of $\mathrm{ET}_{\mathrm{o}}$ for the Ebro valley are more realistic when $R_{\mathrm{a}}$ is estimated from a DTM and GIS modelling. This method captures differences in $\mathrm{ET}_{\mathrm{o}}$ values for slopes of different aspects. These differences are enhanced during the winter months because of the increased influence of topography on $R_{\mathrm{a}}$ distribution at this time of year. Some local differences are also observed in the summertime $\mathrm{ET}_{\mathrm{o}}$ maps in which $R_{\mathrm{a}}$ is modelled solely as a function of latitude. These differences are mainly evident in areas with the most complex topography, such as in the Pyrenees. In any case, the use of $R_{\mathrm{a}}$ estimates obtained from a DTM results in superior spatial models, with higher coefficients of determination than those estimates based on the assumption of a planar surface. This indicates a greater spatial detail in maps made from $R_{\mathrm{a}}$ estimates in which the effect of topography is taken into account. We recommend using this approach when calculating $\mathrm{ET}_{\mathrm{O}}$.

Equally important as the method of estimating $R_{\mathrm{a}}$ is the use of geographic and topographic predictor variables when modelling spatial variations in $\mathrm{ET}_{\mathrm{o}}$. Generally, only elevation is included as an auxiliary variable when compiling $\mathrm{ET}_{\mathrm{o}}$ maps via geostatistical techniques such as co-kriging (Martínez-Cob and Cuenca, 1992; MartínezCob, 1996; Noshadi and Sepaskhah, 2005; Mardikis et al., 2005) or neural networks (Antonic et al., 2001). These studies have shown that the incorporation of elevation data notably improves the performance of the estimates; however, in the present paper we have demonstrated the even greater potential of regressionbased interpolation and GIS in mapping $\mathrm{ET}_{\mathrm{O}}$. Our method takes into account more variables than just elevation when calculating $\mathrm{ET}_{\mathrm{o}}$. The use of GIS enables easy calculations and the use of independent variables by means of raster layers.

When considering other variables in addition to elevation, a greater spatial variability in $\mathrm{ET}_{\mathrm{o}}$ is observed. This observation indicates that the influence of elevation may vary over the study site and that other variables also influence spatial variations in $\mathrm{ET}_{\mathrm{O}}$. The method used in the present study also allows us to consider possible orographic effects at different spatial scales by the use of low-pass filters. This feature is very useful because we have shown that the spatial scale used to measure elevation can change month-by-month when elevation is included in the $\mathrm{ET}_{\mathrm{o}}$ modelling.

Another interesting methodological task addressed in this study is assessing the convenience of assuming possible error propagations in map calculations if the maps are obtained from continuous layers of climatic data or directly modelling local $\mathrm{ET}_{\mathrm{o}}$ estimates. Our results indicate that regardless of the method used to estimate $R_{\mathrm{a}}$, it is preferable to model in advance the variables involved in $\mathrm{ET}_{\mathrm{o}}$ calculation and calculate $\mathrm{ET}_{\mathrm{o}}$ via GIS layer algebra than directly modelling local $\mathrm{ET}_{\mathrm{o}}$ estimates. This finding is explained by the fact that maximum and minimum temperatures are more easily 
modelled (higher $R^{2}$ coefficients) than local $\mathrm{ET}_{\mathrm{o}}$ values. Despite an element of error propagation in the layer algebra operations (Arbia et al., 1998; Heuvelink, 1998), errors can be assumed to be low for the different maps (between 1 and $11 \mathrm{~mm} \mathrm{month}{ }^{-1}$, depending of the month and method of estimating $R_{\mathrm{a}}$ ). To locally calculate $\mathrm{ET}_{\mathrm{o}}$, different variables are involved: maximum and minimum temperatures and $R_{\mathrm{a}}$. This makes $\mathrm{ET}_{\mathrm{o}}$ modelling more difficult than the approach that involves obtaining independent models for each variable. For the Ebro valley, the coefficients of determination for maximum and minimum temperatures vary between 0.60 and 0.86 as a function of the month of the year, while $\mathrm{ET}_{\mathrm{o}}$ varies between 0.52 and 0.77 ( $R_{\mathrm{a}}$ from a planar surface) and 0.62 and $0.79\left(R_{\mathrm{a}}\right.$ from a DTM and GIS modelling). The $\mathrm{D}$ used to validate the maps always shows better results for $\mathrm{ET}_{\mathrm{o}}$ obtained from layer algebraic operations than for the direct modelling of local $\mathrm{ET}_{\mathrm{o}}$ calculations. Therefore, the first approach should be used when creating maps of $\mathrm{ET}_{\mathrm{o}}$ for regions with highly complex topography.

Another advantage of this procedure is that, with an increased availability of data, more climatic layers are easily included in the calculation of $\mathrm{ET}_{\mathrm{o}}$, using modified HG equations to improve the calibration with PM under specific conditions. Therefore, for some areas, the inclusion of the rate of the average temperature to the average daily temperature range (Amatya et al., 1995), a rainfall term (Droogers and Allen, 2002), or wind speed (Martínez-Cob and Tejero-Yuste, 2004) in the original $\mathrm{HG}$ equation leads to a better estimate of $\mathrm{ET}_{\mathrm{o}}$.

\section{ACKNOWLEDGEMENTS}

This work has been supported by the project CGL200504508/BOS financed by the Spanish Comission of Science and Technology (CICYT) and FEDER, PIP176/2005 financed by the Aragón Government, and 'Programa de grupos de investigación consolidados' (BOA 48 of 20-04-2005), also financed by the Aragón Government. Research of the third author was supported by postdoctoral fellowship by the Ministerio de Educación, Cultura y Deporte (Spain).

\section{REFERENCES}

Agnew MD, Palutikof JP. 2000. GIS-based construction of base line climatologies for the Mediterranean using terrain variables. Climate Research 14: 115-127.

Alexandersson H. 1986. A homogeneity test applied to precipitation data. Journal of Climatology 6: 661-675.

Allen RG, Smith M, Perrier A, Pereira LS. 1994. An update for the definition of reference evapotranspiration. ICID Bulletin 43: 1-34.

Allen RG, Pereira LS, Raes D, Smith M. 1998. Crop Evapotranspiration: Guidelines for Computing Crop Requirements, Irrigation and Drainage Paper 56. FAO: Roma, Italia.

Amatya DM, Skaggs RW, Gregory JD. 1995. Comparison of methods for estimating REF-ET. Journal of Irrigation and Drainage Engineering-ASCE 121: 427-435.

Antonic O, Krizan J, Marki A, Bukovec D. 2001. Spatio-temporal interpolation of climatic variables over large region of complex terrain using neural networks. Ecological Modelling 138: 255-263.
Arbia G, Griffith D, Haining R. 1998. Error propagation modelling in raster GIS: overlay operations. International Journal of Geographical Information Science 12: 145-167.

Austin RB, Cantero-Martínez C, Arrúe JL, Playán E, CanoMarcellán P. 1998. Yield-rainfall relationships in cereal cropping systems in the Ebro river valley of Spain. European Journal of Agronomy 8: 239-248.

Basist A, Bell GD, Meentemeyer V. 1994. Statistical Relationships between topography and precipitation patterns. Journal of Climate 7: $1305-1315$.

Begueria S, Vicente-Serrano SM. 2006. Mapping the hazard of extreme rainfall by peaks-over-threshold extreme value analysis and spatial regression techniques. Journal of Applied Meteorology and Climatology 45: 108-124.

Berengena J, Gavilán P. 2005. Reference evapotranspiration estimation in a highly advective semiarid environment. Journal of Irrigation and Drainage Engineering-ASCE 131: 147-163.

Blackie JR, Simpson TKM. 1993. Climatic variability within the Balquhidder catchments and its effect on penman potential evapotranspiration. Journal of Hydrology 145: 371-387.

Bonacina LCW. 1945. Orographic rainfall and its place in the hydrology of the globe. Quarterly Journal of the Royal Meteorological Society 71: 41-55.

Braun-Blanquet J, Bolós O. 1957. Les groupements vegetaux du bassin de l'Ebre. Anales de la Estación Experimental de Aula Dei 5: ${ }^{\circ}$ 1-4.

Brown DP, Comrie AC. 2002. Spatial modeling of winter temperature and precipitation in Arizona and New Mexico, USA. Climate Research 22: 115-128.

Burrough PA, McDonnell RA. 1998. Principles of Geographical Information Systems. Oxford University Press: Oxford.

Choisnel E, de Viellele O, Lacroze F. 1992. Une Approche Uniformisée du calcul de l'evapotranpiration Potentialle Pour l'ensamble des pays de la Communautés Européene. Publication EUR 14223, Office des Publications Officielles des Communauté Européene: Luxembourg.

Dalezios NR, Loukas A, Bampzelis D. 2002. Spatial variability of reference evapotraspiration in Greece. Physics and Chemistry of the Earth 27: 1031-1038.

Daly C, Neilson RP, Phillips DL. 1994. A statistical-topographical model for mapping climatological precipitation over mountainous terrain. Journal of Climate and Applied Meteorology 33: 140-158.

Daly C, Helmer EH, Quinones M. 2003. Mapping the climate of Puerto Rico, Vieques and Culebra. International Journal of Climatology 23: 1359-1381.

Daly C, Gibson WP, Taylor GH, Johnson GL, Pasteris P. 2002. A knowledge-based approach to the statistical mapping of climate. Climate Research 22: 99-113.

Doorenbos J, Pruitt WO. 1977. Crop Water Requirements, Irrigation and Drainage Paper. No. 24. FAO: Rome, Italy; 144.

Droogers P, Allen RG. 2002. Estimating reference evapotranspiration under inaccurate data conditions. Irrigation and Drainage Systems 16: $33-45$.

Dubayah R, Rich PM. 1995. Topographic solar radiation models for GIS. International Journal of Geographical Information Systems $\mathbf{9}$ 405-419.

Dyras I, Dobesch H, Grueter E, Perdigao A, Tveito OE, Thornes JE, van der Wel F, Bottai L. 2005. The use of geographic information systems in climatology and meteorology: COST 719. Meteorological Applications 12: 1-5.

Embid A. 2003. The transfer from the Ebro basin to the Mediterranean basins as a decision of the 2001 national hydrological plan: the main problems posed. International Journal of Water Resources Development 19: 399-411.

Gavilán P, Lorite IJ, Tornero S, Berengena J. 2006. regional calibration of Hargreaves equation for estimating reference ET in a semiarid environment. Agricultural Water Management 81: 257-281.

González-Rouco JF, Jiménez JL, Quesada V, Valero F. 2001. Quality control and homogeneity of precipitation data in the Southwest of Europe. Journal of Climate 14: 964-978.

Haining RP, Arbia G. 1993. Error propagation through map operations. Technometrics 35: 293-305.

Hair JF, Anderson RE, Tatham RL, Black WC. 1998. Multivariate Data Analysis. Prentice Hall International, Inc.: New York; 799.

Häntzschel J, Goldberg V, Bernhofer C. 2005. GIS-based regionalisation of radiation, temperature and coupling measures in complex terrain for low mountain ranges. Meteorological Applications 12 . $33-42$. 
Hargreaves GL. 1985. Defining and using reference evapotranspiration. Journal of Irrigation and Drainage Engineering-ASCE 120 1132-1139.

Hargreaves GL, Samani ZA. 1985. Reference crop evapotranspiration from temperature. Applied Engineering in Agriculture 1: 96-99.

Hargreaves GL, Allen RG. 2003. History and evaluation of Hargreaves evapotranspiration equation. Journal of Irrigation and Drainage Engineering-ASCE 129: 53-63.

Herrero J, Aragüés R. 1988. Suelos afectados por salinidad en Aragón. Surcos de Aragón 9: 5-11.

Heuvelink GBM. 1998. Error Propagation in Environmental Modelling with GIS. Taylor \& Francis: London.

Heuvelink GBM, Burrough PA. 2002. Developments in statistical approaches to spatial uncertainty and its propagation. International Journal of Geographical Information Science 16: 111-113.

Heuvelink GBM, Borrough PA, Stein A. 1989. Propagation of errors in spatial modelling with GIS. International Journal of Geographical Information Systems 3: 303-322.

Hong Y, Nix HA, Hutchinson MF, Booth TH. 2005. Spatial interpolation of monthly mean climate data for China. International Journal of Climatology 25: 1369-1379.

Itenfisu D, Elliott RL, Allen RG, Walter IA. 2000. Comparison of reference evapotranspiration calculations across a range of climates. Proceedings of the $4^{\text {th }}$ National Irrigation Symposium. ASAE: Phoenix, AZ.

Jensen ME, Burman RD, Allen RG. 1990. Evapotranspiration and irrigation water requirements. Committee on Irrigation Water Requirements of the Irrigation and Drainage Division of American Society of Civil Engineers (ASCE): New York.

Karssenberg D, De Kong K. 2005. Dynamic environmental modelling in GIS: 2. Modelling error propagation. International Journal of Geographical Information Science 19: 623-637.

Kumar L, Skidmore AK, Knowles E. 1997. Modelling topographic variation in solar radiation in a GIS environment. International Journal of Geographical Information Science 11: 475-497.

Lantner DP, Veregin H. 1992. A research paradigm for propagation errors inlayer-based GIS. Photogrammetric Engineering and Remote Sensing 57: 677-687.

Lanzante JR. 1996. Resistant, robust and non-parametric techniques for the analysis of climate data: theory and examples, including applications to historical radiosonde station data. International Journal of Climatology 16: 1197-1226.

Lasanta T, Vicente Serrano SM, Cuadrat JM. 2005. Spatial-temporal variability of the plant landscape in the mediterranean highlands due to the abandonment of traditional land uses: a study of the Spanish Central Pyrenees. Applied Geography 25: 47-65.

Lasanta T, Pérez Rontomé MC, Machín J, Navas A, Mosch W, Maestro M. 2001. La exportación de solutos en un polígono de regadío de Bardenas (Zaragoza). Cuaternario y Geomorfología 15 $51-66$.

López-Moreno JI, García Ruiz JM. 2004. Influence of snow accumulation and snowmelt on streamflow in the Central Spanish Pyrenees. International Journal of Hydrological Sciences 49 787-802.

López-Moreno JI, Nogués-Bravo D. 2005. A generalized additive model for modelling the spatial distribution of snowpack in the Spanish Pyrenees. Hydrological Processes 19: 3167-3176.

López-Moreno JI, Beguería S, García Ruiz JM. 2002. Influence of the Yesa reservoir on floods of the Aragón River, central Spanish Pyrenees. Hydrology and Earth System Sciences 6: 753-762.

López-Moreno JI, Hess T, White S. 2003. Estimation of reference evapotranspiration in the upper Aragón River Basin, with PenmanMonteith equation using easily available meteorological data. Geophysical Research Abstracts 5: 1027.

López-Moreno JI, Beguería S, García-Ruiz JM. 2005. The management of a large mediterranean reservoir: storage regimes of the Yesa reservoir, Upper Aragón River basin, Central Spanish Pyrenees. Environmental Management 34: 508-515.

Mardikis MG, Kalivas DP, Kollias VJ. 2005. Comparison of interpolation methods for the prediction of reference evapotranspiration - An application in Greece. Water Resources Management 19: 251-278.

Martínez-Cob A. 1996. Multivariate geostatistical analysis of evapotranspiration and precipitation in mountainous terrain. Journal of Hydrology 174: 19-35.

Martínez-Cob A. 2002. Infraestimación de la evapotranspiración potencial con el método de Thornthwaite en climas semiáridos. In La Información Climática Como Herramienta de Gestión Ambiental Cuadrat JM, Vicente y SM, Saz MA (eds). Universidad de Zaragoza: Zaragoza; 117-122.
Martínez-Cob A, Cuenca RH. 1992. Influence of elevation on regional evapotranspiration using multivariate geostatistics for various climatic regions in Oregon. Journal of Hydrology 136: 353-380.

Martínez-Cob A, Tejero-Juste M. 2004. A wind-based qualitative calibration of the Hargreaves ETo estimation equation in semiarid regions. Agricultural Water Management 64: 251-264.

McKenney DW, Mackey BG, Zavitz BL. 1999. Calibration and sensitivity analysis of a spatially-distributed solar radiation model. International Journal of Geographical Information Science 13: 49-65.

Mitasova H, Mitas L. 1993. Interpolation by regularized Spline with tension. Mathematical Geology 25: 641-655.

Ninyerola M, Pons X, Roure JM. 2000. A methodological approach of climatological modelling of air temperature and precipitation through GIS techniques. International Journal of Climatology 20: 1823-1841

Ninyerola M, Pons X, Roure JM. 2006. Objective air temperature mapping for the Iberian Peninsula using spatial interpolation and GIS. International Journal of Climatology (In press).

Noshadi M, Sepaskhah AR. 2005. Application of geostatistics for potential evapotranspiration estimation. Iranian Journal of Science and Technology Transaction B-Engineering 29: 343-355.

Pereira LS, Perrier A, Allen RG. 1999. Evapotranspiration: concepts and future trends. Journal of Irrigation and Drainage EngineeringASCE 125: 45-51.

Perry M, Hollis D. 2005. The development of a new set of long-term climate averages for the UK. International Journal of Climatology 25: $1023-1039$.

Peterson TC, Easterling DR. 1994. Creation of homogeneous composite climatological reference series. International Journal of Climatology 14: 671-679.

Peterson TC, Easterling DR, Karl TR, Groisman P, Nicholls N, Plummer N, Torok S, Auer I, Boehm R, Gullett D, Vincent L, Heino R, Tuomenvirta H, Mestre O, Szentimrey T, Salinger J, Førland EJ, Hanssen-Bauer I, Alexandersson H, Jones P, Parker D. 1998. Homogeneity adjustments of in situ atmospheric climate data: a review. International Journal of Climatology 18: 1493-1517.

Pons X. 1996. Estimación de la Radiación Solar a partir de modelos digitales de elevaciones. Propuesta metodológica. In VII Coloquio de Geografía Cuantitativa, Sistemas de Información Geográfica y Teledetección, Juaristi JI, Moro I (eds). Vitoria-Gasteiz: Vitoria; 87-97.

Pons X. 2006. Manual of miramon. Geographic Information System and Remote Sensing Software. Centre de Recerca Ecològica i Aplicacions Forestals (CREAF): Bellaterra, (http://www.creaf.uab.es/ miramon)

Ray SS, Dadhwal VK. 2001. Estimation of crop evapotranspiration of irrigation command area using remote sensing and GIS. Agricultural Water Management 49: 239-249.

Sánchez-Toribio MI. 1992. In Métodos para el estudio de la evaporación y evapotranspiración, Cuadernos Téncicos de la S.E.G Ed. Geoforma: Logroño.

Sharma ML. 1985. Estimating evapotranspiration. In Advances in Irrigation, Vol 3, Hillel D (ed.). Acain Press: London.

Štěpánek P. 2004. AnClim - Software for Time Series Analysis (for Windows). Department of Geography, Faculty of Natural Sciences, Masaryk University: Brno, 1.47 MB.

Tsanis IK, Naoum S. 2003. The effect of spatially distributed meteorological parameters on irrigation and water demand assessment. Advances in Water Resources 26: 311-324.

Tabony RC. 1985. Relations between minimum temperature and topography in Great Britain. Journal of Climatology 5: 503-520.

Temesgen B, Eching S, Davidoff B, Frame K. 2005. Comparison of some reference evapotranspiration equations for california. Journal of Irrigation and Drainage Engineering-ASCE 131: 73-84.

Ustrnul Z, Czekierda D. 2005. Application of GIS for the development of climatological air temperature maps: an example from Poland. Meteorological Applications 12: 43-50.

Vicente-Serrano SM. 2006. Evaluating the impact of drought using remote sensing in a mediterranean, Semi-arid region. Natural Hazards (In press). DOI:10.1007/S11069-006-0009-7.

Vicente-Serrano SM, Beguería S. 2003. Estimating extreme dry-spell risk in the middle Ebro valley (Northeastern Spain): a comparative analysis of partial duration series with a General Pareto distribution and Annual maxima series with a Gumbel distribution. International Journal of Climatology 23: 1103-1118.

Vicente-Serrano SM, Cuadrat JM. 2006a. Trends in drought intensity and variability in the middle Ebro valley (NE Spain) during the 
second half of the twentieth century. Theoretical and Applied Climatology (In press). DOI:10.1007/S00704-006-0236-6.

Vicente-Serrano SM, López-Moreno JI. 2006b. The influence of atmospheric circulation at different spatial scales on winter drought variability through a semiarid climatic gradient in north east Spain. International Journal of Climatology 26: 1427-1453.

Vicente-Serrano SM, Saz MA, Cuadrat JM. 2003. Comparative analysis of interpolation methods in the middle Ebro valley (Spain): application to annual precipitation and temperature. Climate Research 24: 161-180.

Vicente-Serrano SM, Cuadrat JM, Romo A. 2006. Aridity influence on vegetation patterns in the middle Ebro valley (Spain): evaluation by means of AVHRR images and climate interpolation techniques. Journal of Arid Environments 66: 353-375.

Walter IA, Allen RG, Elliot R, Mecham B, Jensen M, Itenfisu D, Howell TA, Snyder R, Brown P, Echings S, Spofford T, Hattendorf M, Cuenca R, Wright JL, Martin D. 2000. ASCE standardized reference evapotranspiration equation, p 209-215. In Proceedings
National Irrigation Symposium, Evans RG, Benham BL, Trooien TP (eds). ASAE: Phoenix, AZ.

Willmott CJ. 1981. On the validation of models. Physical Geography 2: 184-194.

Willmott CJ. 1982. Some comments on the evaluation of model performance. Bulletin of the American Meteorological Society 63: $1309-1313$.

Willmott CJ, Matsuura K. 2005. Advantages of the mean absolute error (MAE) over the root mean square error (RMSE) in assessing average model performance. Climate Research 30: 79-82.

Willmott CJ, Matsuura K. 2006. On the use of dimensioned measures of error to evaluate the performance of spatial interpolators. International Journal of Geographical Information Science 20: 89-102.

Xu CY, Singh VP. 2001. Evaluation and generalization of temperaturebased methods for calculating evaporation. Hydrological Processes 15: $305-319$. 